\title{
RECEPCJA TWÓRCZOŚCI LITERACKIEJ MAKSYMA GORKIEGO W POLSCE
}

\author{
PIOTR GŁUSZKOWSKI \\ Uniwersytet Warszawski \\ Wydział Lingwistyki Stosowanej, Katedra Rusycystyki \\ ul. Szturmowa 4, 02-678 Warszawa \\ e-mail: p.gluszkowski@uw.edu.pl \\ ORCID: 0000-0002-6820-7302 \\ (nadesłano: 2.11.2019; zaakceptowano: 15.11.2019)
}

\section{Abstract \\ Reception of Maxim Gorky's Literary Works in Poland}

The paper explores the reception of Maxim Gorky's literary works in Poland in 19002018. At the beginning of the 20th century Gorky was among the most-translated Russian authors. Translations of his works were published in the former Polish territories under all partitions (Russian, Prussian and Austrian). In the years 1918-1939/1945, despite anti-Soviet attitudes of a significant part of Polish society, Gorky was still very popular. In the times of the Polish People's Republic (1945-1989), the writer was characterized by the historians of Russian literature as a classic Soviet writer and the founder of the Socialist Realism. Polish scholars usually repeated views of their Soviet colleagues. Recently Gorky's works attract attention rather of Polish writers and publicists (Józef Hen, Adam Michnik, Sylwia Frołow, Krzysztof Varga) than of historians of literature.

Key words: Maxim Gorky, Alexei Peshkov, reception, Józef Hen, Russia, USSR, Russian literature 
Резюме

\section{Восприятие литературного творчества Максима Горького в Польше}

В статье представлены особенности восприятия литературного творчества Максима Горького в Польше в 1900-2018 гг. В начале XX в. его произведения часто переводились на польский язык (в Российской империи, Австро-Венгрии и Германии). В 1920-1930 гг., несмотря на антисоветские настроения, Горький пользовался в Польше большой популярностью. В 1945-1989 гг. польские литературоведы, вслед за советскими учеными, представляли Горького как классика советской литературы и основателя методы соцреализма. В последнее время к творчеству Горького чаще обращаются писатели и публицисты (Юзеф Хен, Адам Михник, Силвия Фролов, Кшиштоф Варга), чем историки литературы.

Ключевые слова: Максим Горький, восприятие, Юзеф Хен, Россия, СССР, русская литература

Maksym Gorki to z pewnością jeden z najbardziej znanych pisarzy rosyjskich. Na swą popularność pracował od 1892 roku, kiedy to zaczął przygodę z literaturą jako nikomu nieznany pisarz-samouk. Już po kilku latach był jednym z najchętniej czytanych rosyjskich dramaturgów i beletrystów. Po śmierci Antona Czechowa i Lwa Tołstoja stał się najpopularniejszym autorem w Rosji. Gorki przez wiele lat walczył z caratem, nic więc dziwnego, że uznaje się go za jeden z symboli rewolucji rosyjskiej. Po jego książki sięgali chętnie nie tylko Rosjanie, ale również zachodnioeuropejscy czytelnicy. Na początku XX stulecia znaczną część jego utworów przetłumaczono na kilkanaście języków europejskich. Po rewolucji 1917 roku, mimo że krytykował przewrót październikowy i poczynania Lenina, był zdecydowanie najpopularniejszym prozaikiem w Rosji bolszewickiej. Szczyt jego sławy przypadł na przełom lat 20. i 30. XX wieku, kiedy powrócił do Związku Sowieckiego. Nakłady jego dzieł sięgały wtedy wielu milionów egzemplarzy, a jego autorytet wykraczał daleko poza sfery kulturalno-literackie. Zdaniem części badaczy jedynie uwarunkowania polityczne sprawiły, że Gorki nie otrzymał Literackiej Nagrody Nobla. Marina Cwietajewa wyraziła dezaprobatę po przyznaniu tej nagrody Iwanowi Buninowi w 1933 roku, podkreślając, iż ta bardziej należała się Gorkiemu, który był całą epoką literacką, w odróżnieniu od Bunina będącego jedynie końcem epoki (Марченко 2017: 86, 152).

Gorki to z pewnością postać nieoczywista: z jednej strony walczył o sprawiedliwość społeczną i „lepsze jutro”, pomagał dziesiątkom pisarzy (Wiktor Szkłowski, Władysław Chodasiewicz, Nina Berberowa) i wstawiał się za represjonowanymi „białymi”, w tym za rodziną carską (Wielki Książę Gawriła Romanow), z drugiej zaś legitymizował władzę bolszewików, zaprowadzony przez nich terror czy też budowę Kanału Białomorskiego. Nie ulega jednak wątpliwości, że był to jeden z klasyków prozy rosyjskiej i radzieckiej, którego utwory na trwałe zapisały się w historii literatury. 
Problem z jednoznacznym odczytaniem postawy Gorkiego w latach 1905-1936 (od rewolucji 1905 roku i pierwszej emigracji aż do śmierci) sprawił, że polscy badacze bardzo różnie interpretowali jego dzieła. W artykule pokażę, jak wyglądała recepcja jego twórczości literackiej w Polsce, poczynając od pierwszych przetłumaczonych utworów i wzmianek aż do 2018 roku. Postaram się również wyjaśnić, co spowodowało, iż twórczość Gorkiego była tak różnie oceniana przez naukowców oraz dlaczego w ostatnim dziesięcioleciu częściej jest tematem refleksji publicystów, pisarzy i badaczy teatru niż literaturoznawców. Swe rozważania rozpocznę od kwestii: dlaczego trudno pisać obiektywnie o Gorkim i dlaczego nie powstała jeszcze jego wyczerpująca biografia naukowa.

Maksym Gorki doczekał się wielu biografii, szkiców i artykułów. Najwięcej z nich powstało w Związku Sowieckim, w którym przedstawiano go jako przyjaciela Lenina, Stalina i innych bolszewików, a także jako wzór dla młodych literatów. Przez wiele lat był tam na równi z Puszkinem najchętniej wspominanym i cytowanym pisarzem. W latach 1955-1960 co roku pisano ponad 600 prac na temat jego życia i twórczości (Лукирская, Морщихина 1965).

W latach 80. Nina Berberowa, pracując nad biografią jego kochanki, baronowej Mury Budberg, zauważyła:

Jeśli chodzi o Gorkiego, to nie doczekał się do dziś biografii. (...) Jego listy są wydane we fragmentach i z pewnością nie wszystkie, jego zdjęcia ucierpiały od czerwonego ołówka cenzora, jego stosunki z współczesnymi mu są wypaczone. Trzy tomy Летописи жизни и творчества [Kroniki życia i twórczości - P.G.] roją się od błędów i niedoróbek: imiona wymienione w indeksie nie znalazły się w tekście, a imiona $\mathrm{z}$ tekstu nie weszły do indeksu; wyszczególnione są odjazdy, ale nie ma przyjazdów (i na odwrót); można znaleźć listy odebrane, a brak wysłanych (i na odwrót). Jego wyjazd z Piotrogrodu do Moskwy w 1920 roku w ogóle nie został zanotowany (Берберова 1997: 206).

Do podobnego wniosku doszedł w latach 90. profesor Donald Fanger; wyrażał zdziwienie, iż nikt dotąd nie odważył się stworzyć szczegółowej biografii pisarza. Żadna ze znanych mu rosyjskich i angielskich prac nie pretenduje do miana „pełnowymiarowej monografii" (Fanger 1998: 283-284).

Od owych wypowiedzi upłynęło kilka dziesięcioleci - wciąż brak jest kanonicznego opracowania biografii Gorkiego. Rosyjscy badacze po upadku Związku Sowieckiego przez długi czas nie zajmowali się tą postacią. Oczywiście można mówić o wyjątkach ${ }^{1}$, ale nie ma wątpliwości, że na kilkanaście lat pisarz popadł w „niełaskę” środowiska naukowego. Jest to zrozumiałe, gdyż wielu naukowców było przekonanych, iż przez lata siłą narzucany temat twórczości Gorkiego został wyczerpany.

Sytuacja zmieniła się blisko dziesięć lat temu, kiedy w obiegu naukowym zaczęły się pojawiać nowe źródła, przede wszystkim licząca przeszło dziesięć tysięcy listów korespondencja pisarza znajdująca się w archiwum Instytutu Literatury Światowej Rosyjskiej Akademii Nauk (Спиридонова 2010; 2014; Московская 2018). Z perspektywy czasu i w świetle nowych dokumentów można spojrzeć na Gorkiego inaczej: nie ma już konieczności pisania o nim z pozycji marksizmu, nie ma już tematów tabu (kry-

1 Wszystkie prace Wadima Baranowa, Ludmiły Spiridonowej i Natalii Primoczkiny, którzy bez względu na koniunkturę rzetelnie badali twórczość Gorkiego. 
tyka rewolucji październikowej, stosunek do Lenina, redakcja gazety „Nowaja Żyzń” stojącej w opozycji do „Prawdy” i zamkniętej przez bolszewików itd.) (Głuszkowski 2019: 41-51). Kilkudziesięciu rosyjskich literaturoznawców co roku publikuje nowe materiały dotyczące twórcy.

W XXI wieku powstało kilka biografii Gorkiego, jednak większość z nich jest skierowana do masowego czytelnika i ma na celu przede wszystkim popularyzację twórczości pisarza (Басинский 2006; Петелин 2007; Быков 2016; Никитин 2018). W ostatnich latach napisano dwie biografie polityczne oparte na źródłach, które niestety po macoszemu traktują twórczość literacką autora Matki (Yedlin 1999; Чони 2018). Wydaje się, że główną przyczyną braku wyczerpującej biografii jest pojawianie się zbyt dużej liczby nowych faktów, co jest efektem kwerend badaczy publikujących nowe źródła. Najbardziej znani badacze twórczości Gorkiego boją się uogólnień i pominięcia licznych faktów, dlatego koncentrują się głównie na odmitologizowaniu jego postaci i pracach poświęconych jednemu wybranemu problemowi (Спиридонова 1994, 2004, 2013). Ogrom spuścizny literackiej pozostawionej przez pisarza oraz szeroki krąg jego znajomości i działalności sprawiają, że nikt jeszcze nie podjął się napisania wyczerpującej biografii. Z pewnością Gorki jest na nowo odkrywany przez rosyjskich badaczy, co najlepiej pokazał 2018 rok, w którym obchodzono jubileusz 150-lecia narodzin pisarza i który zaowocował dziesiątkami nowych wartościowych prac.

Jak już wspominałem, Maksym Gorki wdarł się na literacki Parnas w Rosji i szybko zyskał uznanie rosyjskich czytelników (Rudziewicz 2013: 91-98). Polacy żyjący w Cesarstwie Rosyjskim i czytający po rosyjsku mogli poznawać jego twórczość już od 1892 roku. Jego młodzieńcze utwory były często niedopracowane pod względem warsztatowym, co nie osłabiało ich wydźwięku, a dodatkowo wzmacniało nimb pisarza-samouka, który prostymi zdaniami opisywał problemy nizin społecznych (głównie robotników). Na pierwsze przekłady na język polski trzeba było czekać zaledwie kilka lat. Już w 1900 roku wydano pierwszy tom opowiadań, który szybko znalazł swoich czytelników i stał się sygnałem do tłumaczeń kolejnych utworów. O popularności Gorkiego na początku XX wieku w Polsce świadczy liczba przekładów Pieśni o zwiastunie burzy - w samym 1902 roku została przełożona przez trzech tłumaczy i wydrukowana we wszystkich trzech zaborach, w sumie przetłumaczono ją kilkanaście razy (zob. Grzegorczyk 1955: 725-726). Do 1918 roku na język polski przełożono większość przedrewolucyjnych utworów Rosjanina, w tym wybór pism w dwóch tomach $z$ lat 1904-1906 (Sielicki 1968: 89). Gorki na początku XX wieku był już bardzo znanym pisarzem, w związku z czym wydawnictwa nie ryzykowały wiele, decydując się na opublikowanie jego utworów. Te sprzedawały się dobrze we wszystkich zaborach. Szczególnie dużą popularnością cieszył się wśród komunizujących robotników. W 1905 roku wyrazili oni poparcie dla Gorkiego w związku z jego manifestem o rewolucji 1905 roku i zaangażowaniem w obalenie caratu. Dużą sympatię zdobył też wśród galicyjskich chłopów, którzy z jego twórczością mogli się zapoznać na łamach „Przyjaciela Ludu” (Sielicki 1969: 163).

Warto dodać, że utwory Gorkiego wystawiano na scenach wszystkich trzech zaborów, np. Mieszczanie byli grani w Krakowie (1902), Lwowie (1903), Przemyślu (1913), Poznaniu (1903), Warszawie (1906) i Łodzi (1910), również Na dnie i Dzieci słońca 
weszły do repertuaru polskich teatrów w Austro-Węgrzech, Cesarstwie Rosyjskim i Niemczech (Sielicki 1968: 105).

Z pewnością lata 1918-1939 to ciekawy okres w polskiej recepcji dzieł Gorkiego. Nieprzypadkowo powstało już na ten temat kilka prac (Ryter 1967; Sielicki 1969: 163-184). Z racji stosunkowo dobrego rozpoznania problemu przez innych badaczy wspomnę jedynie o najważniejszych tendencjach z tego okresu. Warto podkreślić, że w międzywojniu Gorki był rozpoznawany przez przeciętnego polskiego czytelnika. Ukazała się wtedy większość przekładów jego utworów pisanych podczas „drugiej” emigracji, choć nie były one już tak popularne jak Matka i autobiograficzna trylogia.

Po odzyskaniu niepodległości przez Polskę zainteresowanie dziełami Gorkiego wzrosło. Wpłynęło na to kilka czynników. Przede wszystkim Rosja bolszewicka, a potem Związek Sowiecki były jednym z dwóch głównych wrogów odrodzonej Polski. Nic więc dziwnego, że Gorki, uważany za ikonę rewolucji, szybko stał się obiektem zainteresowania licznych polskich badaczy. Większość potępiała go, traktując jako bolszewika dążącego do rozpętania permanentnej rewolucji i nie zagłębiając się w jego teksty. Dobrym przykładem będzie spojrzenie Stanisława Zdziarskiego, który w 1919 roku na podstawie wybranych tekstów pisarza stwierdził, że ten nawołuje do anarchii, sam zaś jest epigonem i satelitą Lwa Tołstoja i Fiodora Dostojewskiego - „heroldów anarchii” (Zdziarski 1919: 38). Według niego młodzieńcze utwory Gorkiego były napisane $\mathrm{z}$ „niepospolitą energią i siłą”, dzięki czemu przynajmniej do 1905 roku wyrażał społeczny protest. Niestety, czas pokazał, że ze szlachetnego protestu pozostały jedynie zużyte slogany. „(...) kiedy pseudo-rewolucja wypełzła ze swoich nor podziemnych, okazało się, że hasła one wszystkie górnolotne rozpadły się, jak łachmany spłowiałe i zelżałe, bo nie pochodziły z duszy człowieczej, ale ze zwierzęcej pożądliwości" (Zdziarski 1919: 38). Zdziarski dokonał również analizy najgłośniejszej powieści pisarza - Matki. „Według Gorkiego należy odrzucić wszelką kulturę oraz zasady, na jakich opiera się państwo i społeczeństwo. Celem zaś życia - dogodzenie instynktom bydlęcym, i w tym kierunku człowiek nie powinien spotykać żadnych przeszkód. Tak głosił współczesny Zarathustra rosyjski..." (Zdziarski 1919: 100) - dodawał ironicznie polski badacz. Zdziarski, podobnie jak znaczna część polskich krytyków, utożsamiał Gorkiego z bolszewikami, krwawą rewolucją, terrorem i groźbami wobec Polski. Pobieżna znajomość jego dzieł sprawiała, że wielu polskich badaczy nie miało pojęcia, iż w latach 1917-1918 wydał w gazecie „Nowaja Żyzń” cykl artykułów zatytułowany Myśli nie na czasie. Głównym tematem kilkudziesięciu tekstów była właśnie kultura w czasie rewolucji, którą Gorki rozumiał inaczej niż bolszewicy. Dlatego też wielokrotnie nawoływał do ochrony dóbr kultury, ratowania plądrowanych bibliotek, pomocy pisarzom i artystom, a także cywilizowania prymitywnej i zezwierzęconej Rosji poprzez kulturę. Protestował również przeciwko anarchii: „Z anarchią zawsze wypada walczyć, ale czasem trzeba też umieć przezwyciężyć swój własny strach przed ludem" (Gorki 2016b: 461). Wybiórcze analizowanie twórczości Gorkiego sprawiało, że tysiące Polaków traktowało go jako nowego Czyngis-Chana (Sielicki 1969: 166-167).

Polscy krytycy literaccy praktycznie nie komentowali sporu Gorkiego z bolszewikami; nie zastanawiali się nad przyczyną jego emigracji i związkami z ZSRS po śmierci Lenina. Krytyczne wypowiedzi pisarza o bolszewikach były chętnie odnotowywane przez polską prasę, jednak rzadko opatrywano je wyjaśnieniem. Geneza konfliktu po- 
zostawała dla przeciętnego polskiego czytelnika nieznana, a głównym celem wzmianek o listach Gorkiego do władz ZSRS była chęć pokazania problemów narastających wśród bolszewików (Niewdzięczny Gorki 1925).

W 1932 roku w związku z 40-leciem działalności literackiej rosyjskiego twórcy ukazał się m.in. artykuł Jana Bersona - sowietologa związanego z obozem sanacyjnym - który również stanowi dobry przykład podejścia znacznej części polskich czytelników do Gorkiego: „Dla nas, Polaków, był, jest i pozostanie na wieki - obcym, egzotycznym, wrogim nawet, choć pełnym talentu, zjawiskiem. Obcy był jako «bosiak», może jeszcze bardziej obcy jest jako bolszewicki «państwowiec»" (Otmar 1932: 3). Z pewnością na stosunek większości Polaków do Gorkiego wpłynął jego powrót do Związku Sowieckiego. I choć pisarz nie przerwał działalności literackiej, dla wielu polskich publicystów stał się urzędnikiem legitymizującym władzę sowiecką. Na recepcję jego twórczości nie wpłynęło ocieplenie polsko-sowieckich stosunków na przełomie lat 20. i 30., którego rezultatem było podpisanie paktu o nieagresji w 1932 roku.

Nie oznacza to jednak, że Polacy nie czytali Gorkiego. Wśród robotników był on jednym z najpopularniejszych pisarzy (Hryniewicz 1932: 54). Jego utwory i wypowiedzi o nim publikowano w „Kulturze Robotniczej”, „Naprzód” „Gazecie Robotniczej” czy „Robotniku”. Najbardziej obiektywne informacje zamieszczały periodyki literackie z poczytnymi „Wiadomościami Literackimi” na czele. W międzywojniu trudno było ignorować Gorkiego, którego sztuki chętnie grano w teatrach niemalże całej Europy, a jego samego często wskazywano jako głównego kandydata do Literackiej Nagrody Nobla (również w 1924 roku, kiedy to nagroda została przyznana Władysławowi Reymontowi). O Gorkim wspominali też najwybitniejsi polscy humaniści, m.in. Aleksander Brückner, Marian Zdziechowski czy Jan Kucharzewski, przyznając, że nie sposób zajmować się Rosją, czy też literaturą rosyjską, nie uwzględniając jego utworów.

Po 1945 roku polscy czytelnicy zostali zmuszeni do masowego czytania literatury rosyjskiej i sowieckiej. Gorki, którego w ZSRS uznano za wzór do naśladowania dla pisarzy socrealizmu, stał się jednym z najczęściej drukowanych autorów zagranicznych, a jego książki automatycznie trafiły na listę lektur. Warto podkreślić, że znaczna część korespondencji i publicystyki pisarza z lat 1917-1933 została celowo „zapomniana” przez sowieckich historyków literatury, a w rezultacie także polskich. Dobrym przykładem są 16-tomowe Pisma. W tomie 16 poświęconym korespondencji za lata 1917-1919 nie znajdziemy żadnego listu (Gorki 1957). Pisarz prowadził wtedy ożywioną korespondencję $\mathrm{z}$ wieloma osobami i wielokrotnie wyrażał swoje niezadowolenie z przejęcia władzy przez Lenina. Próżno również wśród dzieł Gorkiego doszukiwać się cyklu Myśli nie na czasie, mimo że sam autor wydał go w oddzielnej książce, która do ZSRS trafiła dopiero w czasie pierestrojki. Można odnieść wrażenie, że polscy historycy literatury rosyjskiej unikali pisania o Gorkim. Nie powstała żadna biografia autora Matki, a polscy badacze zdecydowanie chętniej zajmowali się wczesną twórczością pisarza niż okresem porewolucyjnym. Sytuacja ta dobrze świadczy o polskim literaturoznawstwie czasów PRL. Potencjalni gorkoznawcy wiedzieli, że ich prace będą porównywane z monografiami i artykułami sowieckich badaczy, zdawali sobie sprawę, że nie otrzymają wglądu do wszystkich dokumentów z archiwum Gorkiego (kilkanaście tysięcy listów) oraz że będą musieli cenzurować lata 1917-1921 i znaczną część jego wypowiedzi z okresu sowieckiego. 
Polscy badacze unikali podawania informacji o krytycznym podejściu Gorkiego do przewrotu bolszewickiego. Jako jeden z nielicznych Jerzy Lenarczyk tłumaczył jego postawę strachem przed ,anarchistycznym wybuchem żywiołu drobnomieszczaństwa i chłopstwa” i „niewiarą w możliwość zwycięstwa rewolucji socjalistycznej w kraju zacofanym gospodarczo i kulturalnie" (Lenarczyk 1966: 47). Polscy badacze z obowiązku powoływali się na sowieckich klasyków literaturoznawstwa (np. Anatolija Łunaczarskiego), podkreślając międzynarodowe znaczenie Gorkiego, jego wpływ na rozwój sowieckiej literatury, walkę z caratem i literaturą mieszczańską (Lenarczyk 1966: 49; Jakóbiec 1976: 505-541). Nic więc dziwnego, że wiele trudnych miejsc jego biografii próbowano omijać. I tak np. Jerzy Lenarczyk, wyjaśniając emigrację Gorkiego w latach 20. XX wieku, ograniczył się jedynie do informacji, że wyjazd odbył się „ze względów zdrowotnych i za radą Lenina" (Lenarczyk 1966: 48).

Zarówno Lenarczyk, jak i inni polscy autorzy dużą uwagę poświęcali kwestii „Gorki a sprawa polska”. Mottem do zgłębiania tego zagadnienia były słowa samego pisarza z listu do publicysty i krytyka literackiego Wilhelma Feldmana: „Jako człowiek, który chyli czoła przed narodem polskim, niezmordowanym w swej walce o wolność, jestem gorącym wielbicielem literatury polskiej i cieszyłbym się niezmiernie, gdybym mógł zapoznać naród rosyjski z życiem duchowym jego braci złączonych z nim wspólnotą krwi” (Gorki 1960: 527-528). Z perspektywy czasu śmiało można powiedzieć, że Gorki nie interesował się szczególnie Polską i jej kulturą. Znał jednak wielu polskich pisarzy i kanon literatury polskiej. Jego kontakty z Polakami i literaturą polską były także jednym z głównych kierunków poszukiwań Franciszka Sielickiego, który w swej monografii opisał literackie spotkania Gorkiego z polską klasyką: Henrykiem Sienkiewiczem, Władysławem Reymontem, Stefanem Żeromskim, Stanisławem Brzozowskim (Sroka 1958: 115-128; Lenarczyk 1969: 172-195; Sielicki 1971).

Tak jak przed wojną, tak i po 1945 roku dramaty Gorkiego były chętnie wystawiane na deskach polskich teatrów. Przeszło 25 jego utworów doczekało się inscenizacji w teatrach kilkunastu polskich miast. Przy okazji niektórych spektakli krytycy teatralni przypominali czytelnikom rolę i znaczenie Gorkiego. Dobrym przykładem jest recenzja Jegora Bułyczowa wystawionego w Warszawie przez Teatr Śląski na deskach Teatru Polskiego napisana przez Tadeusza Brezę. Autor zachwycał się sztuką, wychwalając wielkość pisarza: „Gorki, to nie dramatopisarz, to żywioł. Trudno o jego dialogach mówić jak o dialogach, bo w pojęciu dialogu tkwi poniekąd jakaś misterność, a w słowie Bułyczowa nie ma misterności, tak jak jej nie ma w Niagarze. Jest siła, pełnia, skala! (...) Cóż to za pisarz" (Breza 1966: 350-351).

$\mathrm{Na}$ Gorkiego inaczej patrzyła polska emigracja. Pojawiał się w wypowiedziach i felietonach jej najwybitniejszych przedstawicieli. Gustaw Herling-Grudziński poświęcił mu nawet szkic, w którym próbował wyjaśnić zagadkę jego śmierci (Herling-Grudziński 1997: 299-331). Pisał o Gorkim jak o twórcy, który dla stabilizacji finansowej i „wygodnego życia" sprzedał się Stalinowi i swym nazwiskiem firmował budowę komunizmu z Kanałem Białomorskim na czele (Горький, Авербах, Фирин 1934).

Po 1989 roku polscy badacze nie byli już zmuszani do wybierania tematów zgodnych z sowieckimi badaniami nad literaturą. Wraz z licznymi zagadnieniami dotyczącymi polsko-rosyjskiej współpracy rewolucyjno-wyzwoleńczej porzucono praktycznie problem analizy twórczości rosyjskiego pisarza. Matka Gorkiego została usunięta 
z listy lektur w polskich szkołach średnich, Gorki przestał być autorytetem, znaczna część jego utworów nie przetrwała nawet na liście lektur rusycystyk.

Jeszcze przed ostatecznym upadkiem ZSRS Rosjanom udało się doprowadzić do wydania Myśli nie na czasie. Część $\mathrm{z}$ artykułów ukazała się nawet w przekładzie na język polski w drugim obiegu, jednak nie wzbudziła większego zainteresowania historyków literatury rosyjskiej i rosjoznawców (Gorki 1986). Temat cyklu podjął jedynie Franciszek Sielicki, ale w swym artykule starał się tonować spór pomiędzy bolszewikami i Gorkim (Sielicki 1987: 41-56). Do wydania kolejnej części Gorkowskich felietonów w Polsce doszło dopiero w 1998 roku w poświęconym temu twórcy numerze „Literatury na Świecie" (nr 10). Była to pierwsza próba głębszej refleksji nad Gorkim po latach posuchy. Wybór tekstów miał za zadanie pokazać polskiemu czytelnikowi, jak błędna była interpretacja światopoglądu pisarza w czasach PRL. W numerze oprócz wspomnień o Gorkim (Nina Berberowa, Władysław Chodasiewicz, Jurij Annienkow) pojawiły się prace współczesnych badaczy (Wiaczesław Iwanow, Donald Fanger) i wreszcie niepublikowane wcześniej utwory pisarza, w tym wybrane artykuły z cyklu Myśli nie na czasie (Gorki 1998: 80-116).

Na przełomie XX i XXI wieku Gorkim w Polsce zajmowały się pojedyncze osoby. Jedną z nich był Józef Hen, który w 2006 roku napisał powieść w znacznej mierze poświęconą temu autorowi. Osią powieści były dwa przemieszane ze sobą wątki: jeden dotyczył amerykańskiego slawisty prowadzącego prywatne śledztwo $\mathrm{w}$ sprawie zmarłego przyjaciela, drugi zaś, zdecydowanie ciekawszy, dotyczył przełomowych momentów w życiu Maksyma Gorkiego. Książka pełna jest cytatów z wypowiedzi autora Matki oraz innych wybitnych pisarzy z jego otoczenia. Bez wątpienia Hen przeprowadził kwerendę, wczytując się dokładnie w dzieła swojego bohatera oraz wspomnienia kontrowersyjnej Niny Berberowej. Z narracji Hena wynika, że Gorki był postacią wielką i tragiczną. Pomagał wszystkim i tylko dzięki niemu przeżyli Władysław Chodasiewicz, Nina Berberowa, Wiktor Szkłowski i wielu innych pisarzy (Hen 2006). Dzięki wnikliwej lekturze cyklu Myśli nie na czasie Hen trafnie zauważył, że dla Gorkiego najważniejsze było zakończenie „wielkiej wojny” i ocalenie rosyjskiej kultury przed zniszczeniem (głównie przed rewolucją i wojną domową). Pisarz rzeczywiście bał się, że rewolucja zniszczy Rosję bardziej niż jarzmo tatarsko-mongolskie i wszystkie wcześniejsze wojny. Najciekawsze wydają się jednak obszerne fragmenty dotyczące relacji pomiędzy Leninem i Gorkim. Mimo że na ten temat napisano setki prac, do dzisiaj jest to kwestia sporna, która czeka na opublikowanie nowych źródeł². Hen pisał, że Lenin i Gorki znali się wyjątkowo dobrze i darzyli się szacunkiem, podkreślał również, iż nie było żadnego innego pisarza, który przez tyle lat dyskutowałby z przywódcą bolszewików. Gdyby Gorki pisał o swoim Leninie, „byłaby to rzecz o człowieku, który chciał bogom wykraść ogien - i przeliczył się z siłami. Bo całe zamierzenie było nie na miarę rodzaju ludzkiego. Wziął na siebie straszliwy ciężar - i zginął przywalony tym ciężarem. Bo czymże innym była jego choroba niż krachem pokonanego organizmu?" (Hen 2006). Hen opisywał Gorkiego i Lenina z pasją równą Aleksandrowi Sołżenicynowi,

2 Gorki napisał szkic na temat swych relacji, który później gruntownie przeredagował i „wygładził”. W ostatnich latach pojawiły się nowe listy Gorkiego do Lenina. 
który stworzył portret tego drugiego na marginesie wielotomowego Czerwonego koła traktującego o upadku Cesarstwa Rosyjskiego (Sołżenicyn 1990).

Bez wątpienia coraz mniej Polaków zna Gorkiego, choćby z tego powodu, że od ćwierć wieku próżno szukać go w kanonie lektur. Jednak sytuacja ta pozwala wielu osobom „odkryć” pisarza bez ideologicznego balastu. Wydaje się, że taki cel postawiła przed sobą publicystka Sylwia Frołow, która w 2016 roku w książce Bolszewicy i apostołowie. Osiem portretów zamieściła obszerny szkic Mistrz i dyktatorzy ogólnie opowiadający o życiu i znaczeniu Gorkiego (Frołow 2014: 13-111). Dla młodszych czytelników, którzy nie znali wcześniej „zwiastuna rewolucji” lub mieli o nim mgliste wyobrażenie jako o jednym $z$ wielu pisarzy sowieckich, szkic ten musiał być bardzo odkrywczy. Autorka koncentrowała się głównie na okresie porewolucyjnym, dużo uwagi poświęciła kobietom w życiu Gorkiego i tajemnicy jego śmierci. Próbowała również pokazać fenomen Gorkiego, który w ciągu kilku lat stał się jednym z najbardziej znanych pisarzy w Rosji i chyba jako jedyny ze świadków rewolucji cieszył się popularnością zarówno w Cesarstwie Rosyjskim, jak i w ZSRS. Bez wątpienia jest to świetny materiał dla dziennikarza piszącego z zacięciem historycznym i chyba jedyny sposób, aby przywrócić zainteresowanie Gorkim wśród przeciętnych polskich czytelników.

Maksym Gorki pojawia się również jako pomysłodawca i redaktor monografii zbiorowej Kanał Białomorsko-Bałtycki imienia Stalina: historia budowy 1931-1934 w książce Mariana Sworzenia poświęconej biografiom sowieckich luminarzy wychwalających budowę Kanału Białomorskiego. Publicysta przedstawił Gorkiego jako sowieckiego „arcykapłana”, który sprzedał się Stalinowi w zamian za dostatnie życie i „rząd dusz” (Sworzeń 2017: 17, 19). Nie miał wątpliwości, że Gorki był budowniczym morderczego systemu i jego beneficjentem, za co powinien zostać osądzony przez mieszkańców dzisiejszej Rosji. Sworzeń błędnie sugeruje czytelnikom, że rosyjski twórca nie miał zasad i obojętne mu było, czy mieszka w faszystowskich Włoszech, komunistycznym Związku Sowieckim czy też innym państwie. Szkic ten jest dobrym przykładem próby zaszufladkowania Gorkiego i przedstawienia go jedynie jako pisarza, który za profity sprzedał się Sowietom. Autor pracy o sowieckich luminarzach zapomniał o złożonym tle historycznym, mając pretensje do Gorkiego m.in. za to, że ten w latach 30. potępiał zwalczany przez siebie od dziesięcioleci carat (Sworzeń 2017: 17, 19).

Mimo że w Polsce panuje moda na nowe przekłady klasyki rosyjskiej (np. Bracia Karamazow Fiodora Dostojewskiego, Wykop/Dół Andrieja Płatonowa, Mistrz i Matgorzata Michaiła Bułhakowa), to twórczość Gorkiego przez długi czas nie mogła się doczekać nowego tłumaczenia ${ }^{3}$. Jest to tym dziwniejsze, że nie wszystkie utwory pisarza ukazały się w Polsce, a nawet krytycy nieprzepadający za Gorkim przyznają, iż jego dzieła należą do klasyki literatury światowej. Z tym większą radością należy odnotować wydaną w 2016 roku książkę Rosja zawierającą w znacznej mierze nieznane polskiemu czytelnikowi utwory Maksyma Gorkiego ${ }^{4}$. Oprócz poszerzonego przekładu felietonów z cyklu Myśli nie na czasie do tomu weszły tzw. Portrety literackie, czyli wspomnienia Gorkiego o pisarzach (m.in. Antonie Czechowie, Sergieju Jesieninie,

3 Po 1989 roku została wznowiona jedynie Matka w serii Arcydzieła Literatury Światowej wydawanej przez madryckie wydawnictwo Club International de Libro Polska: (Gorki 2000).

4 Tłumaczem jest Małgorzata Buchalik (Gorki 2016b). 
Lwie Tołstoju), działaczach społecznych i politykach (Włodzimierzu Leninie, Sawwie Morozowie) oraz Rosji z czasów jego młodości. Warto pochylić się nad wstępem pióra Adama Michnika, który już w pierwszych zdaniach zauważył, że książka pokazuje nam Gorkiego, „jakiego nie znamy. Znamy ikonę literatury stalinowskiej, nudnego i spodlonego piewcę sowieckiego komunizmu, którego doszczętnie obrzydziły kilku pokoleniom obowiązkowe lektury szkolne. Ale oto inny Maksym Gorki - bystry obserwator Rosji rewolucyjnej i bolszewickiej, namiętny krytyk carskiego samodzierżawia i okrutnej dyktatury” (Michnik 2016: V). Wielokrotnie powtarzający, że jest „antysowieckim rusofilem", i świetnie oczytany w literaturze rosyjskiej Michnik zdumiał się, że Gorkiego nie można zaszufladkować jako pisarza, „który stał się twarzą dla stalinowskiej polityki mordu i upodlenia kultury rosyjskiej", gdyż była to postać o wiele bardziej skomplikowana, o wielu odcieniach szarości. Dotychczasowa postawa Michnika jest charakterystyczna dla polskiej inteligencji wychowanej w czasach PRL, która najczęściej ma już z góry wyrobione zdanie na temat Gorkiego i, niestety, przekazuje je młodszemu pokoleniu.

W omawianiu postrzegania Gorkiego w ostatnich latach nie sposób pominąć przetłumaczonej na język polski książki Diavolina węgierskiego pisarza György Spiró o Olimpiadzie Czertkowej - służącej, opiekunce i prawej ręce Maksyma Gorkiego (Spiró 2017). Jest to kolejna próba ukazania autora Matki jako pisarza uwikłanego w politykę, który często musiał ratować się kłamstwem, aby wybrać mniejsze zło (powrót do ZSRS, wyjazd na Sołowki itd.). Podobnie jak w przypadku Hena widać, że postać Gorkiego zafascynowała Spiró. Węgierski pisarz wyraźnie próbował zrozumieć jego motywy działania i wyjaśnić, jakie relacje panowały pomiędzy nim i sowiecką władzą; jaki miał stosunek do Lenina i Stalina; czy powrócił z emigracji ze względu na brak pieniędzy, chęć sprawowania władzy czy też szczerze wierzył, że państwo Stalina zamienia się w komunistyczny raj? Diavolina stała się dla pisarza i publicysty Krzysztofa Vargi inspiracją do refleksji na temat Gorkiego i jego stosunku do władzy w czasach totalitaryzmu. Varga nie ma wątpliwości, że Gorki został wykorzystany przez Stalina: „Fascynujące, jak bardzo artyści lgną do władzy, jak władza artystom imponuje, gdy tymczasem władza wyłącznie artystami się wysługuje, jeśli akurat są jej potrzebni” (Varga 2017). Podkreślał jednak, że rosyjski pisarz nie był wyjątkiem i również wielu innych wybitnych artystów dało się uwieść i wykorzystać tyranom.

Gorkiego usunięto w Polsce z kanonu lektur szkolnych, na próżno szukać nowych wydań, a tym bardziej nowych przekładów jego najbardziej znanych dzieł w księgarniach i bibliotekach, pozostał za to na deskach teatru. Tak jak na początku XX stulecia, tak i dziś największą popularnością cieszą się Letnicy (grani w 12 teatrach po 1989 roku) ${ }^{5}$, Na dnie (9), Wassa Żeleznowa (3), Barbarzyńcy (2), Dzieci słońca, Mieszczanie, Jegor Bułyczow i inni (1). Próbę czasu i zmianę systemu przetrwała tylko klasyka, a mniej znane dramaty są wystawiane z rzadka lub w ogóle. Z pewnością Gorki nie jest ulubionym obiektem sporów krytyków teatralnych, choć w specjalistycznej prasie pojawiają się artykuły na temat inscenizacji jego sztuk (Kocur 2006: 14-15; Łapicka

5 Dnia 9 listopada 2019 roku w Teatrze Narodowym odbyła się premiera Letników w reżyserii Macieja Prusa. 
2016: 58-59; Wakar 2016: K4; Kociński 2017: 64). Popularność Gorkiego w teatrze została również odnotowana przez rusycystów (Krycka-Michnowska 2018: 216-232).

Zaskakujące jest, jak rzadko literaturoznawcy sięgają do spuścizny Gorkiego. Oprócz Pauliny Baranowskiej, która w 2013 roku opublikowała kilka artykułów w prestiżowych rusycystycznych czasopismach i obroniła pracę doktorską o typologii postaci w jego wczesnej twórczości (Baranowska 2013a: 197-224; 2013b 126-133; 2015), próżno szukać badaczy zajmujących się jego utworami, nie mówiąc już o szerszym spojrzeniu na jego poglądy i działalność pozaliteracką. Oczywiście prace o Gorkim powstają, jednak są to pojedyncze artykuły, najczęściej pisane na marginesie innych tematów badawczych (Madej-Cetnarowska 2008: 121-133). Wzmianki o Gorkim częściej pojawiają się w tłumaczeniach prac zachodnich badaczy lub w literaturze wspomnieniowej (Berberowa 1998; Figes 2009; Nabokov 2017: 399-414). Kolejnym potwierdzeniem niedużego zainteresowania polskich badaczy rosyjskim klasykiem była zorganizowana 10-11 października 2019 roku w Katedrze Rusycystyki Uniwersytetu Warszawskiego konferencja „Bunin vs Gorki. Między jubileuszami”, w której zdecydowaną większość uczestników stanowili obcokrajowcy.

W artykule starałem się prześledzić recepcję dzieł Gorkiego w Polsce, poczynając od pierwszych wzmianek o pisarzu i tłumaczeń jego utworów na przełomie XIX i XX wieku, a kończąc na najnowszych artykułach poświęconych jego twórczości. Generalizując, można stwierdzić, że do 1918 roku polscy czytelnicy poznawali Gorkiego i szczerze zachwycali się jego twórczością. Lata międzywojnia to fascynacja pomieszana z niechęcią i wrogością, na którą wpłynęły relacje polsko-sowieckie. Bez wątpienia w latach 20. i 30. XX wieku polscy czytelnicy (i to nie tylko intelektualiści) znali dobrze twórczość Gorkiego, dużo pisano na jego temat i chętnie tłumaczono najważniejsze utwory. Kolejny okres to lata PRL, kiedy rosyjski pisarz był przedstawiany jako jeden z klasyków literatury światowej. Na język polski tłumaczono nie tylko jego utwory, ale również jego korespondencję i prace gorkoznawców. Wielka szkoda, że po 1989 roku twórczość Gorkiego jest obecna w zasadzie tylko w teatrze. Brakuje nowych tłumaczeń, nowych wydań i przede wszystkim nowego spojrzenia na jego twórczość. W 1966 roku René Śliwowski w przedmowie do wydania korespondencji Gorkiego z innymi pisarzami stwierdzał: „(...) z tych obecnie udostępnianych materiałów wyłania się nowa sylwetka Gorkiego - krytyka, biografa, historyka literatury, wydawcy, protektora młodych talentów. (...) Postać Gorkiego wyłania nam się w całej złożoności, zostaje niejako odbrązowiona, a przez to staje się bliższa, zrozumialsza, plastyczniejsza i prawdziwsza" (Śliwowski 1966: 11). Po wydaniu nowych źródeł, zarówno tych z okresu Cesarstwa Rosyjskiego, jak i Związku Sowieckiego, pochodzących z Rosji/ZSRS i emigracji, po dziesiątkach ważnych publikacji, które ukazały się nie tylko w Federacji Rosyjskiej i wreszcie po refleksji na temat Gorkiego pióra znanych pisarzy warto znów pochylić się nad twórczością „Zwiastuna rewolucji”.

\section{Bibliografia}

Baranowska, P. (2013a). „Kwestia kobieca” w twórczości Maksyma Gorkiego. Slavia Orientalis, 2(62): $197-224$. 
Baranowska, P. (2013b). Patriarchat na zakręcie: kobieta i mężczyzna w Rosji na przełomie XIX i XX wieku (opowiadanie Maksyma Gorkiego Urlop). Przegląd Rusycystyczny, 2(35): 126-133.

Baranowska, P. (2015). Typologia postaci we wczesnej twórczości Maksyma Gorkiego. Niepublikowana rozprawa doktorska napisana pod kierunkiem prof. dr hab. A. Wołodźko-Butkiewicz, Uniwersytet Warszawski, Wydział Lingwistyki Stosowanej, Warszawa, http://depotuw.ceon.pl/handle/ item/1465 (dostęp 15.09.2018).

Basinskij, P.V. (2006). Gor'kij. Moskva: Molodaâ gvardiâ [Басинский, П.В. (2006). Горький. Москва: Молодая гвардия].

Berberowa, N. (1998). Podkreślenia moje. Autobiografia. Przeł. E. Siemaszkiewicz. Warszawa: Noir sur Blanc.

Berberova, N. (1997). Čajkovskij; Železnaâ ženŝina. Moskva: Izdatel'stvo imeni Sabašnikovyh [Берберова, Н. (1997). Чайковский; Железная женщина. Москва: Издательство имени Сабашниковых].

Breza, T. (1966). Krasnowiecki i inni - za: Lenarczyk, J. Maksym Gorki. Warszawa: Państwowe Zakłady Wydawnictw Szkolnych.

Bykov, D. (2016). Gor'kij. Moskva: Molodaâ gvardiâ [Быков, Д. (2016). Горький. Москва: Молодая гвардия].

Čoni, P. (2018). Gor'kij - politik. Sankt Peterburg: Aletejâ [Чони, П. (2018). Горький - политик. Санкт Петербург: Алетейя].

Fanger, D. (1998). Niezwykłe sprzeczności Maksyma Gorkiego. Przeł. J. Jarniewicz. Literatura na Świecie, 10: 283-291.

Figes, O. (2009). Tragedia narodu. Rewolucja rosyjska 1891-1924. Przeł. B. Hrycak. Wrocław: Wydawnictwo Dolnośląskie.

Frołow, S. (2014). Apostołowie i bolszewicy. Osiem portretów. Wołowiec: Czarne.

Głuszkowski, P. (2019). Polemika Maksyma Gorkiego z kadetami i bolszewikami na łamach gazety „Nowaja Żyzń”. Acta Neophilologica, 1(21): 41-51.

Gor'kij, M., Averbah, L.L., Firin, S.G. (Red.) (1934). Belomorsko-baltijskij kanal imeni Stalina: istoriâ stroitel'stva. Moskva: Ob’edinenie gosudarstvennyh knižno-žurnal'nyh izdatel'stv [Горький, М., Авербах, Л.Л., Фирин, С.Г. (Ред.) (1934). Беломорско-балтийский канал имени Сталина: история строительства. Москва: Объединение государственных книжно-журнальных издательств].

Gorki, M. (1957). Wybór listów. W: Gorki, M. Pisma. T. 16. Przeł. J. Dmochowska. Warszawa: Państwowy Instytut Wydawniczy: 203-205.

Gorki, M. (1960). Nieznany list Maksyma Gorkiego. Slavia Orientalis, 4: 527-528.

Gorki, M. (1986). Myśli nie na czasie. Przeł. A. Poraj (J. Lubach). Warszawa: Wydawnictwo WIS.

Gorki, M. (1998). Niewczesne rozważania. Przeł. J. Gondowicz. Literatura na Świecie, 10: 80-116.

Gorki, M. (2000). Matka. Przeł. H. Górska. Warszawa: Club Internacional del Libro Polska.

Gorki, M. (2016a). Myśli nie na czasie. W: Gorki, M. Rosja. Przeł. M. Buchalik. Kraków: Universitas: 415-537.

Gorki, M. (2016b). Rosja. Przeł. M. Buchalik. Kraków: Universitas.

Grzegorczyk, P. (1955). Nota bibliograficzna. W: Gorki, M. Pisma w 16 tomach. T. 5. Warszawa: Państwowy Instytut Wydawniczy: 725-726.

Hen, J. (2006). Bruliony Profesora T. Warszawa: Państwowy Instytut Wydawniczy.

Herling-Grudziński, G. (1997). Siedem śmierci Maksyma Gorkiego. W: Herling-Grudziński, G. Godzina cieni: eseje. Warszawa: Czytelnik: 299-331.

Hryniewicz, Z. (1932). Czytelnictwo w bibliotekach Robotniczych Związków Zawodowych. Warszawa. Jakóbiec, M. (Red.) (1976). Historia literatury rosyjskiej. T. 2. Warszawa: Państwowe Wydawnictwo Naukowe: $505-541$. 
Kociński, W. (2017). Na śmietniku życia. Śląsk: Miesięcznik Społeczno-Kulturalny, 5: 64.

Kocur, M. (2006). O uciekaniu z teatru. Teatr, 11: 14-15.

Krycka-Michnowska, I. (2018). Dramaturgia Maksyma Gorkiego w Polsce. Studia Interkulturowe Europy Wschodniej, 11: 216-232.

Łapicka, K. (2016). Upragniona wizyta. Teatr, 3: 58-59.

Lenarczyk, J. (1966). Maksym Gorki. Warszawa: Państwowe Zakłady Wydawnictw Szkolnych.

Lenarczyk, J. (1969). Maksym Gorki a literatura polska. W: Fiszman, S., Sierocka, K. (Red.). O wzajemnych powiązaniach literackich polsko-rosyjskich. Wrocław: Zakład Narodowy im. Ossolińskich: 172-195.

Lukirskaâ,K.P., Morîihina, A.S. (1965). Literatura o M. Gor'kom. Bibliografiâ 1955-1960. Moskva: Nauka [Лукирская, К.П., Морщихина, А.С. (1965). Литература о М. Горьком. Библиограбия 1955-1960. Москва: Наука].

Madej-Cetnarowska, M. (2008). O nowym „Zwiastunie burzy” Maksyma Gorkiego. Literacka i transpozycja filozofi „wspólnego czynu” Nikołaja Fiodorowa. W: Słowianie w Europie. T. 3. Kraków: Colegium Columbinum: 121-133.

Marčenko, T.V. (2017). Russkâ̂ literatura v zerkale Nobelevskoj premii. Moskva: Azbukovnik [Марченко, Т.В. (2017). Русская титература в зеркале Нобелевской премии. Москва: Азбуковник].

Michnik, A. (2016). Przedmowa. W: Gorki, M. Rosja. Kraków: Universitas: V-VII.

Nabokov, V. (2017). Wykłady o literaturze rosyjskiej. Przeł. Z. Batko. Warszawa: Aleteja: 399-414.

Moskovskaâ, D.S. (Red.) (2018). M. Gor'kij i A. Bogdanovič: družba roždennaâ na beregah Volgi. Moskva: Hudožestvennaâ literatura [Московская, Д.С. (Ред.) (2018). М. Горький и А. Богданович: дружба рожденная на берегах Волги. Москва: Художественная литература].

Niewdzięczny Gorki (1925). Gazeta Poranna, 7392.

Nikitin, E. (2018). Sem' žiznej M. Gor'kogo. Nižnij Novgorod: Dekom [Никитин, Е. (2018). Семь жизней М. Горького. Нижний Новгород: Деком].

Otmar [Berson, J.] (1932). Jubileusz Maksyma Gorkiego. Gazeta Polska, 273: 3.

Petelin, V. (2007). Žizn’ Makima Gor'kogo. Moskva: Centroligraf [Петелин, В. (2007). Жизнь Макима Горького. Москва: Центролиграф].

Rudziewicz, I. (2013). Vospriâtie v Pol'še v načale XX veka Gor'kovskih literaturnyh dostiženij i podhodak kul'turnomu razvitiû. Acta Polono-Ruthenica, 17: 91-98 [Rudziewicz, I. (2013). Восприятие в Польше в начале XX века Горьковских литературных достижений и подхода к культурному развитию. Acta Polono-Ruthenica, 17: 91-98].

Ryter, Z. (1967). Maksym Gorki w krytyce polskiej do roku 1939, http://dspace.uni.lodz.pl:8080/ xmlui/handle/11089/22517 (dostęp 10.09.2018).

Sielicki, F. (1968). Gorki w przekładach i na scenie Polski międzywojennej. Przegląd Humanistyczny, 5: 89-109.

Sielicki, F. (1969). Gorki w polskiej krytyce lat 1918-1939. Slavia Orientalis, 2: 163-184.

Sielicki, F. (1971). Maksym Gorki w kręu spraw polskich. Warszawa: Instytut Wydawniczy Pax.

Sielicki, F. (1987). Felietony Maksyma Gorkiego z cyklu „Myśli nie na czasie”. Rusycystyczne Studia Literaturoznawcze, 10, s. 41-56.

Śliwowski, R. (1966). Wstęp. W: Korespondencja Maksyma Gorkiego z pisarzami. Warszawa: Książka i Wiedza: 8-12.

Sołżenicyn, A. (1990). Lenin w Zurychu. Przeł. P. Herzog. Warszawa: Editions Spotkania.

Spiridonova, L.A. (1994). M. Gor'kij: dialog s istoriej. Moskva: Nasledie [Спиридонова, Л.А. (1994). М. Горький: диалог с историей. Москва: Наследие]. 
Spiridonova, L.A. (2004). Novyj vzglâd. Moskva: Institut mirovoj literatury imeni A.M. Gor'kogo Rossijskoj akademii nauk [Спиридонова, Л.А. (2004). Новый взгляд. Москва: Институт мировой литературы имени А.М. Горького Российской академии наук].

Spiridonova, L.A. (Red.) (2010). Gor'kij v zerkale èpohi: neizdannaâ perepiska. Moskva: Institut mirovoj literatury imeni A.M. Gor'kogo Rossijskoj akademii nauk [Спиридонова, Л.А. (Ред.) (2010). Горький в зеркале эпохи: неизданная переписка. Москва: Институт мировой литературы имени А.М. Горького Российской академии наук].

Spiridonova, L.A. (2013). Nastoâsiji Gor'kij: mify i real'nost'. Moskva: Institut mirovoj literatury imeni A.M. Gor'kogo Rossijskoj akademii nauk [Спиридонова Л.А. (2013). Настоящзий Горький: мифы и реальность. Москва: Институт мировой литературы имени А.М. Горького Российской академии наук].

Spiridonova, L.A. (Red.). (2014). Gor'kij: neizvestnye stranicy istorii: materialy $i$ issledovaniâ. Moskva: Institut mirovoj literatury imeni A.M. Gor'kogo Rossijskoj akademii nauk [Спиридонова, Л.А (Ред.) (2014). Горький: неизвестные страницы истории: материалы и исследования. Москва: Институт мировой литературы имени А.М. Горького Российской академии наук]. Spiró, G. (2017). Diavolina. Przeł. I. Makarewicz. Warszawa: Czytelnik.

Sroka, M. (1958). Stanisław Brzozowski i Maksym Gorki. Materiały do biografii Brzozowskiego. Twórczość, 2: 115-128.

Sworzeń, M. (2017). Czarna ikona. Biełomor. Kanał biełomorski. Dzieje. Ludzie. Słowa. Warszawa: Wydawnictwo Sic!.

Varga, K (2017). Pisarz w butach Stalina, czyli artyści i despoci. Gazeta: Duży Format, 22 maja 2017. Wakar, J. (2016). Ludzka menażeria. Dziennik: Gazeta Prawna, 73, dod. Kultura: K 4.

Yedlin, T. (1999). Maxim Gorky: A Political Biography. Westport: Greenwood Publishing Group.

Zdziarski, S. (1919). Dżingis-Chan zmartwychwstały. Studia z psychopatologii rosyjskiej. T. 2. Poznań: Księgarnia Św. Wojciecha. 